\title{
Ozone Therapy in leg ulcers of patients with chronic venous insufficiency
}

\author{
Silvia Menendez-Cepero
}

Collaborator of the National Center for Scientific Research. Havana, Cuba.

\section{ABSTRACT}

\section{OOPEN ACCESS}

\section{Citation \\ Menendez-Cepero S. Ozone Therapy in leg ulcers of patients with chronic venous insufficiency [abstract]. Proceedings of the 5Th WFOT Meeting; 2016 Nov 18-20; Mumbai, India. J Ozone Ther. 2018;2(2). doi: 10.7203/jo3t. 2.2.2018.11128}

\section{Academic Editor}

Jose Baeza-Noci, School of Medicine, Valencia University, SPAIN

\section{Editor}

World Federation of Ozone Therapy, Bolgna, ITALY

\section{Received}

December 9, 2017

\section{Accepted}

December 10, 2017

\section{Published}

March 4, 2018

\section{Intellectual Property}

Silvia Menendez-Cepero. This is an open access article distributed under the terms of the Creative Commons Attribution License (CC BY 4.0), which permits unrestricted use, distribution, and reproduction in any medium, provided the original author and source are credited.

\section{Author Information}

silviamenendez@infomed.sld.cu
The term chronic venous insufficiency - CVI (due to a deep vein thrombosis, valvular insufficiency or both) indicates a pathologic condition characterized by alterations of the venous flow and is the main cause in the formation of ulcers in the lower limbs, creating an important socio-medical problem, which finally leads the patient to a total disability for the rest of his/her life. In healthy leg veins, one-way valves allow blood to move only in one direction: upstream towards the heart. This prevents the backward flow of blood, back down the legs. However, in disease leg veins, the valves are enlarged and retracted, in such way, that they become unable to block the retrograde venous flow being the main cause for the appearance of ulcers in the lower limbs.

Taking into account the different therapeutic effects of ozone as [1,2]: improvement of oxygen metabolism and blood rheologic properties, stimulation of the antioxidant defense system achieving the cell redox balance, modulation of the immunological system and nitric oxide, as well as its great germicide power, among others, the aim of this study was to evaluate the efficacy of ozone therapy on the healing process of chronic ulcers of the lower limb in comparison with conventional treatment. A controlled and randomized phase III clinical trial was performed in 90 hospitalized patients with ulcers (over 2 years of evolution, with a diameter of no less than $5 \mathrm{~cm}$ ) of the lower limbs due to CVI [3].

Efficacy was evaluated according to the least time of hospital stay, which was the necessary time for the lesions to heal or when they were aseptic or their granulation tissue was ready for skin graft. In the cases where the patient did not want to be skin grafted, he/she was discharged and

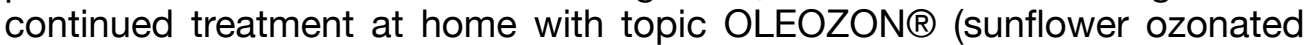
oil).

The sample was divided at random into 3 groups of 30 patients each: 1Control group (conventional treatment): venous repose (leg elevation), hyposodic diet, analgesics, daily cure with saline solution and fomentation with antiseptic solutions, several times per day. 2-Ozone group (M-AHT): venous repose (leg elevation), hyposodic diet, analgesics and local ozone treatment (bagging) and topical OLEOZON ${ }^{\circ}$, once per day, combining with $\mathrm{M}$-AHT (3 times per week), up to 10 sessions $(50 \mathrm{mg} / \mathrm{L}$ and $50 \mathrm{~mL}$ in $100 \mathrm{~mL}$ of blood). 3-Ozone group (Rectal): As M-AHT group but using rectal ozone application up to 20 sessions, once per day $(50 \mathrm{mg} / \mathrm{L}$ and $200 \mathrm{~L})$. No systemic or local antibiotics were used in the study.

Results indicated an average length hospital stay of $(53.1 \pm 13.9) \mathrm{d}$ for the control group and of $(31.5 \pm 6.7) \mathrm{d}$ for both ozone group, with significant differences between control and ozone groups. Therefore, hospital stay was reduced for patients with ulcers in the lower limbs treated by ozone therapy, 
with the subsequent economic saving. No significant differences were observed between the two ozone groups in length hospital stay. No adverse reactions were seen.

Ozone therapy can be considered as another treatment within the therapeutical supply for this condition, which could provide a fast rehabilitation for patients as well as their incorporation to a useful life.

Keywords: ozone therapy, chronic venous insufficiency, ozone rectal insufflation, ozone by major autohemotherapy..

\section{References:}

1. Menendez S, Leon OS, Fernandez JL, Copello M, Weiser MT. Advances of Ozone Therapy in Medicine and Dentistry. La Habana, Cuba: Palacio de las Convenciones; 2016. 513 p. ISBN 978069278138859999.

2. Menendez S, Gonzalez R, Ledea OE, Hernandez F, Leon OS, Diaz M. Ozono. Aspectos basicos y aplicaciones clinicas. La Habana, Cuba: Editorial CENIC; 2008.

3. Quiñones M, Menendez S, Gomez M, et al. Ozonoterapia en el tratamiento de las ulceras de miembros inferiores causadas por insuficiencia venosa cronica. Rev CENIC Ciencias Biologicas 1989;20(1-2-3):76-81. 